\title{
PROBLEMATIKA PEREKRUTAN ANAK DALAM KONFLIK BERSENJATA DAN PERMASALAHANNYA DI INDONESIA ${ }^{1}$
}

\author{
Muh.Risnain \\ Fakultas Hukum Universitas Mataram.
}

\begin{abstract}
The issue of children recruitment in armed conflict will come into contact with the regime of International Law; International Humanitarian Law, International Human Rights Law, International Criminal Law and International Labor Law. The settings in the various legal regimes still leave problems related to the first, there is no uniformity about the minimum age of children who can be recruited as a child, whether 15 or 18 years old? second, legal obligations for the state does not have the same legal force between the obligations that just becomes commemoration to the state or the compulsory obligation.
\end{abstract}

Keywords: Children Recruitment, Armed Conflict.

\begin{abstract}
abstrak
Persoalan perekruatan anak dalam konflik bersenjata akan bersentuhan dengan beberapa rezim hukum internasional: hukum humaniter internasional, Hukum HAM Internasional, Hukum Pidana Internasional, dan Hukum Ketenagakerjaan Internasional. Pengaturan dalam berbagai rezim hukum tersebut masih menyisakan permasalahan terkait dengan : pertama, tidak ada keseragaman tentang usia minimum anak yang dapat direkrut sebagai anak apakah 15 tahun atau 18 tahun? kedua, kewajiban-kewajiban hukum bagi negara tidak memiliki kekuatan hukum yang sama antara kewajiban yang bersifat menyerukan saja kepada negara atau kewajiban yang bersifat wajib (compulsory obligation).
\end{abstract}

Kata kunci: Perekrutan Anak, Konflik Bersenjata

\section{A. Pendahuluan}

Salah satu isu besar yang dihadapi hukum humaniter internasional saat ini adalah persoalan perekrutan anak dalam konflik bersenjata. Laporan UNICEF menunjukkan ada sekitar 300 ribu anak di bawah umur 18 tahun

\footnotetext{
${ }^{1}$ Artikel ini pernah disampaikan dalam acara Basic Course on International Humanitarian Law Kerja sama Fakultas Hukum UGM dan ICRC, tanggal 27-30 Agustus 2013 di Yogjakarta.
} 
telah direkrut dan dieksploitasi sebagai tentara anak (child soldiers) pada sekitar 30 daerah konflik di seluruh dunia. Di antaranya terjadi di Sri Lanka, Kolombia, Myanmar, Chechnya dan Sierra Leone, Republik Demokratik Kongo, dan Sudan. ${ }^{2}$ Ketika agresi militer ke Irak pada tahun 2003 Inggris mengirim 15 tentara yang belum berumur 18 tahun. ${ }^{3}$ Pada tahun 1997 ketika terjadi konflik antara Pemberontak LRA (Lords Resistence Army) dengan tentara Uganda, pemberontak LRA melakukan perekrutan anak-anak yang berumur 8-16 tahun mereka berjenis kelamin laki dan perempuan.

Demikian juga pada Pemerintah Junta Militer Myanmar. Menurut Laporan yang disampaikan Human Right Wath, pemerintah Myanmar melakukan perekrutan anak-anak yang berumur di bawah 10 tahun untuk dijadikan sebagai tentara anak dalam rangka kebijakan pemerintah mengisi kekurangan personil militer, terjadinya desersi personil militer, dan berkurangnya minat warga negara untuk menjadi tentara. Dalam konflik bersenjata yang terjadi di Suriah akhir-akhir ini menurut laporan save the children setidaknya 2 juta anak dibawah usia 18 tahun direkrut sebagai tentara anak dalam konflik bersenjata antara faksi politik di Suriah, anakanak itu dijadikan sebagai kuli, penjaga, informan, tentara, serta menjadi tameng manusia. ${ }^{4}$ Dua negara, Nepal dan Sri Lanka pernah dimasukan dalam daftar hitam PBB sebagai negara-negara yang menggunakan tentara anak. ${ }^{5}$ Anak-anak yang direkrut dilatih menggunakan senjata dan menanamkan sifat permusuhan. Tujuan akhir dari perekrutan tentara anak tersebut sebagai persiapan pasukan yang akan digunakan oleh pemerintah untuk melawan pemberontakkan di negaranya. ${ }^{6}$

Perekrutan anak sebagai tentara dalam konflik bersenjata dari sisi psikologis sangat berbahaya dan merugikan kepentingan sang anak. Anakanak yang direkrut tersebut kemudian dibentuk menjadi pribadi yang tidak sesuai dengan jati sdiri mereka. Mereka diajarkan taktik berperang dan ditanamkan rasa permusuhan dan benci. Dalam pikiran mereka tertanam satu nilai permusuhan dan mereka hanya berpikir bagaimana membunuh dan mempertahankan diri agar tidak menjadi korban pembunuhan. Pembentukan karakter demikian ini membuat anak-anak tersebut tidak mengetahui dunia mereka yang sesungguhnya. Padahal usia dini seperti mereka seharusnya hidup dalam pangkuan dan bimbingan orang tua yang penuh kasih sayang keluarga, bermain, dan mengembangkan potensinya dengan bersekolah dan

\footnotetext{
${ }^{2}$ http://www.tempo.co/read/news.

${ }^{3}$ Ibid.

4 http://www.tempo. co/read/news/2013/03/13/115466746/Perekrutan-Tentara-Anak-diSuriah-Meningkat.

5 http://id.berita.yaho o.com/lima-negara-janji-hentika n-perekrutan-tentara-anak-anak091805356.html.

${ }^{6}$ Suara pembaharuan, edisi, 31 Mei 2007.
} 
bergaul dalam lingkungan. Oleh karena itu, seharusnya anak-anak mereka dilindungi dan tidak menjadi korban dari konflik bersenjata.

Dari sisi hak asasi manusia perekrutan tentara sebagai anak merupakan perbuatan yang melanggar hak asasi anak sebagai pribadi yang merdeka. Ketika anak-anak direkrut sebagai tentara maka mereka tidak dapat menikmati lagi hak mereka sebagai anak seperti hak untuk mendapatkan pendidikan, kasih sayang dari orang tuanya, dan mengembankan potensi diri mereka. Bahkan dalam perekrutan tentara anak tidak jarang pula mendapatkan penyiksaan yang harusnya mereka bebas dari tindakan seperti itu.

Menyadari dampak buruk dari perekrutan anak sebagai tentara dalam konflik bersenjata, masyarakat internasional telah mengatur dengan berbagai perangkat hukum internasional yang mengikat bagi negara-negara. Larangan tersebut diatur dalam empat rezim hukum yang memiliki hubungan dalam perlindungan anak sebagai tentara yaitu, Hukum Humaniter Internasional, Hukum Hak Asasi Manusia Internasional, Hukum Pidana Internasional, dan Hukum Perburuhan Internasional.

Dalam hukum humaniter ketentuan tentang perlindungan anak dari perekrutan anak sebagai tentara diatur dalam konvensi Jenewa tentang perlindungan penduduk sipil tahun 1949, ketentuan serupa juga diatur dalam Protokol Tambahan II Tahun 1977 yang melarang perekrutan anak sebagai tentara. Dalam Hukum Perburuhan Internasional ketentuan larangan menggunakan anak di bawah umur dalam suatu pekerjaan juga melarang dilakukannya perekrutan tentara anak. Dari sisi perlindungan hak asasi anak, perekrutan tentara anak dilarang dalam konvensi internasional tentanghak anak. Perkembangan terakhir dari sisi hukum pidana internasional menentukan pula adanya kewajiban bagi negara untuk tidak menggunakan anak-anak sebagai tentara. Bahkan Statuta Roma 1998 menentukan bahwa perbuatan merekrut anak sebagai tentara merupakan kejahatan perang.

\section{B. Pembahasan}

\section{Perlindungan Hak Anak dari Perekrutan Sebagai Kombatan Pada Saat Konflik Bersenjata dalam Hukum Internasional.}

Hukum Internasional yang berkaitan dengan perlindungan anak dalam konflik bersenjata menurut Ilene Cohen $^{7}$ merupakan rezim hukum yang mengatur hubungan antar negara dan memiliki dampak tidak langsung kepada aktor non-negara seperti individu, entitas non-pemerintah (nongovernment entities), atau kelompok lain, namun demikian tidak menutup kemungkinan kepada individu yang melakukan pelanggaran dapat

\footnotetext{
${ }^{7}$ Ilene Cohen and Guy S Goodwin-ill, Child Soldiers : The Role of Children in Armed Conflict, (Oxford: Clarendon Press, 1997), hlm. 56.
} 
dimintai pertanggungjawaban. Cohen kembali menyatakan, bahwa hukum humaniter internasional yang berlaku untuk konflik bersenjata noninternasional diberlakukan sama antara angkatan bersenjata yang dimiliki oleh pemerintah dengan angkatan bersenjata yang merupakan lawan pemerintah."by contrast the international humanitarian law of internal armed conflicts applies equally to government armedforces and dissident armed groups, that's is to the parties to the conflict". Pertentangan ini menimbulkan persoalan antara dua kepentingan yaitu kepentingan militer dan kemanusiaan. Mengatasi hal ini maka kedua belah pihak yang berkonflik dapat menjadikan norma yang bersumber dari hukum humaniter internasional yang mencakup kebiasaan perang yang diturunkan dari prinsip kemanusiaan dan prinsip yang berasal dari nilai-nilai keyakinan masyarakat. ${ }^{8}$

\section{a. Perlindungan Hak Anak dari Perekrutan Sebagai Tentara Anak dalam Protokol Tambahan I dan II.}

Protokol Tambahan I (protokol additional to the Geneva convention of 12 august 1949, and relating to the protections of victims of international armed conflict) dan protokol tambahan II (protokol additional to the Geneva convention of 12 august 1949, and relating to the protections of victims of Noninternational armed conflict) merupakan perjanjian internasional yang lahir sebagai tindak lanjut dari Konvensi Jenewa yang telah terlebih dahulu ada pada tahun 1949 yang mengatur tentang hukum humaniter. ${ }^{9}$ Kedua konvensi tersebut lahir dari inisaitif organisasi ICRC yang merupakan usaha untuk memperbaharui hukum humaniter dan mengajak negara-negara untuk mengakui dan menerima perubahan dari wajah peperangan selama ini yang cenderung mengabaikan aspek-aspek kemanusiaan. Di samping itu, lahirnya protokol tersebut sebagai jawaban atas banyaknya gerakan pembebasan nasional (national liberation) dan berkembangnya strategi gerilya dalam peperangan yang sering kali mengabaikan aspek-aspek kemanusiaan. Keanggotaan negara dalam Konvensi tambahan tersebut sangat ditentukan oleh keanggotaan negara pada keempat konvensi tersebut, artinya bahwa negara yang dapat menjadi pihak dalam dua Konvensi tersebut jika negara tersebut telah menjadi negara pihak dalam Konvensi Jenewa $1949 .{ }^{10}$ Sampai

\footnotetext{
${ }^{8}$ Ibid.

${ }^{9}$ Konvensi Jenewa yang dimaksud meliputi : Konvensi Jenewa untu Perbaikan Keadaan Luka dan Sakit dalam Angkatan Bersenjata di medan pertempuran darat, Konvensi Jenewa untuk Perbaikan Keadaan Anggota Angkatan Bersenjata di Laut, yang Luka, sakit dan korban karam, Konvensi Jenewa mengenai Perlakuan Tawanan Perang dan Konvensi Jenewa mngenai perlindungan sipil di waktu perang.

${ }^{10}$ Frits Kalsoven dan Leisbeth Zegveld, Constraints on Waging of The War : An Introduction to International Humanitarian Law, (ICRC, 2001), hlm. 83.
} 
pada tahun 2000 sudah ada 157 negara yang menjadi negara pihak dalam kedua konvensi tambahan tersebut. ${ }^{11}$

Kedua Protokol tambahan tersebut membedakan dua bentuk konflik bersenjata yaitu konflik bersenjata yang terjadi antar negara peserta konvensi atau bersifat internasional dan konflik bersenjata yang bersifat noninternasional. Konflik bersenjata antar negara atau konflik internasional adalah konflik bersenjata yang terjadi antara dua atau lebih negara peserta konvensi yang terjadi baik diakui atau tidak diakui oleh salah satu di antara mereka. ${ }^{12}$ Sedangkan konflik bersenjata yang bersifat non-internasional (non-international conflict) merupakan konflik bersenjata yang terjadi pada wilayah dari negara peserta agung konvensi. ${ }^{13}$

Dalam Konvensi Jenewa 1949 maupun protokol tambahan tahun 1977 memiliki ketentuan yang sama dan penting dalam mengatur konflik bersenjata. Ketentuan-ketentuan itu terdapat dalam setiap Konvensi Jenewa yang mengatur hukum humaniter. Ketentuan tersebut baik ditempatkan dalam pasal yang sama maupun dengan redaksi dan isi yang hampir sama. Dalam kepustakaan hukum Hukum Humaniter Internasional ketentuan penting dan sama tersebut disebut sebagai "common articles". ${ }^{14}$

Dalam empat Konvensi Jenewa 1949 perlindugan terhadap anak didasarkan pada kebutuhan khusus perlindungan yang diberikan kepada anak. Perlindungan hukum terhadap anak yang baru lahir diberikan dalam konteks keselamatan sang bayi, yaitu perlindungan anak untuk mendapatkan pelayanan kesehatan dan suasana yang aman. Pada anak yang berumur 12 tahun perlindungan anak dikaitkan dengan kebutuhan penentuan identitas ketika anak-anak itu terpisah dari orang tuanya sebagai akibat dari pertempuran. Anak yang berusia 15 tahun dibutuhkan perlindungan bantuan dan fasilitas kesejahteraan anak. Sedangkan anak yang berumur 18 tahun kebutuhan perlindungan hukum ditujukan kepada larangan kerja paksa dan melawan hukuman mati terhadap anak. ${ }^{15}$

\section{1) Protokol Tambahan I}

11 Ibid.

12 Pasal 2 Konvensi Jenewa yang merupakan ketentuan yang sama dalam semua konvensi Jenewa (common articles).

${ }^{13}$ Frits Kalsoven dan Leisbeth Zegveld, Constraints on...Op.Cit, hlm. 35.

14 Ketentuan yang merupakan Common articles meliputi ketentuan umum (pasal 1,2,3, 6110,) ketentuan hukum terhadap pelanggaran dan penyalahgunaan (pasal 49,50,51 dan 52) dan ketentuan mengenai pelaksanaan dan ketentuan penutup. Lihat Arlina Permanasari, dk., Pengantar Op.Cit, hlm.33, lihat juga, Rudi M Rizki, Kekerasan Seksual Terhadap Perempuan di Daerah Konflik : Peluang Pertanggungjawabanya di Indonesia, Jurnal PAHAM, Edisi Kedua Desember 2004, (Bandung: Fakultas Hukum Universitas Padjajaran, 2004), hlm. 21.

15 Daniel Helle, Optional Protocol on the involment of children in armed conflict to the Convention on the Rights of the Child, (International Redcross Review, 2004), hlm. 15. 
Protokol Tambahan I 1977 merupakan perjanjian internasional yang mengatur konflik bersenjata yang bersifat internasional yang terjadi antar dua negara atau lebih. Ketentuan yang secara spesifik mengatur tentang perlindungan hak anak dari perekrutan sebagai tentara anak diatur dalam Pasal 77 ayat (2) yang menyatakan bahwa :

"the parties to the conflict shall take all feasible measures in order that children who have not attained the age of fifteen years do not take a direct part in hostilities and, in particular, they shall refrain from recruiting them into their forces. In recruiting among persons who have attained the age of fifteen years but not attained the age of eighteen years, the parties of to the conflict shall endeavor to give priority those who are oldest"

Kewajiban yang lahir bagi negara dalam merekrut anak-anak dalam konflik bersenjata adalah kewajiban yang bersifat fleksibel, tidak membebankan kewajiban hukum penuh bagi negara untuk mengambil tindakan hukum yang sepenuhnya untuk mencegah terjadinya perekrutan dan partisipasi bagi negara dalam konflik bersenjata. Kewajiban bagi negara hanyalah untuk menahan diri untuk tidak merekrut anak yang usianya di bawah 15 tahun dalam angkatan bersenjatanya. Ketentuan di atas hanya membatasi kebebasan bagi negara yang terlibat dalam konflik untuk tidak mengikutsertakan anak dalam konflik bersenjata, sedangkan pengakuan bahwa seorang anak yang terlibat dalam konflik bersenjata sebagai anggota angkatan perang tidak menghilangkan status anak tersebut sebagai pihak kombatan.

Terhadap ketentuan tentang perekrutan anak dalam konflik bersenjata menurut Maria Teresa Dutli, ${ }^{16}$ menyatakan bahwa ketentuan tersebut tidak melahirkan kewajiban hukum yang signifikan bagi negara. ketentuan ini berbeda dengan kehendak dari ICRC yang membebankan kewajiban bagi negara untuk mengambil langkah-langkah yang penting (all necessary measures) untuk mencegah terjadinya rekrutmen dan partisipasi anak dalam konflik bersenjata. Ketentuan tersebut hanya mewakili kepentingan negaranegara yang masih menghendaki adanya partisipasi secara sukarela (voluntary participation) anak dalam konflik bersenjata. Implikasinya adalah bahwa negara yang merekrut anak di bawah 15 tahun dianggap tidak melanggar protokol tambahan tersebut. Lebih lanjut menurut Maria Teresa Dutli mengatakan, bahwa seharusnya ketentuan menjangkau kewajiban negara untuk tidak melakukan rekrutmen anak baik secara wajib maupun sukarela jika anak belum mencapai umur 15 tahun.

\footnotetext{
${ }^{16}$ M.T. Dutli, Captured Child Combatant, International Review of the Red Cross, SeptemberOctober 1990, hlm. 421-434, terkutip dalam Daniel Helle, Optional Protocol.Op.Cit, hlm. 54
} 
Kewajiban negara yang lahir dalam perekrutan sebagai tentara anak yang berumur antara 15 sampai 18 tahun, dimana kewajiban tersebut memberikan prioritas bagi anak yang berusia 18 tahun untuk dijadikan sebagai kombatan merupakan kewajiban hukum yang lemah. Dalam praktek negara dalam ketentuan legislasinya memberlakukan usia 18 (delapan belas) tahun sebagai pihak yang dapat terlibat dalam konflik bersenjata. ${ }^{17}$

2) Protokol Tambahan II

Protokol tambahan II merupakan perjanjian internasional tambahan dari Konvensi Jenewa 1949 yang secara khusus mengatur tentang perlindungan korban sengketa bersenjata pada konflik bersenjata noninternasional (non-international armed conflict) atau ketika terjadinya perang saudara (civil war). Dalam hal pengaturan tentang perlindungan anak dari perekrutan sebagai tentara anak dalam konflik bersenjata ketentuan tersebut diatur dalam Pasal 4 ayat (3) huruf (c) yang menyatakan bahwa"children who have not attained the age of fifteen years shall neither be recruited in the armed forces or groups nor allowed to take part in hostilities". Ketentuan ini menegaskan bahwa anak yang berusia di bawah 15 tahun tidak diperbolehkan untuk direkrut menjadi anggota angkatan bersenjata dan tidak diperbolehkan untuk ikut serta dalam pertikaian bersenjata.

Menurut Ilene Cohen and Guy S Goodwin-ill ketentuan di atas, mengalami kesulitan dalam penerapan untuk mengontrol atau mengatur perekrutan oleh negara atau kelompok tertentu dalam merekrut anak di bawah 18 tahun untuk terlibat dalam konflik. Dalam pada itu, tanggungjawab negara untuk taat pada protokol tambahan II ditujukan hanya kepada pihak yang berkonflik, tetapi tidak kepada anak. Sedangkan para perekrut yang memiliki kekuasaan atau kewenangan dalam hal ini pemerintah atau lawannya. ${ }^{18}$

Dalam perspektif hukum, entitas non-pemerintah (nongovernmental entity) sebagaimana pemerintah hanya akan terikat secara formal terikat pada konvensi jika negara tersebut mengikatkan diri dalam perjanjian internasional tersebut atau jika negara tersebut mendeklarasikan diri untuk mentaati hukum humaniter internasional. Namun, bagaimanapun baik negara maupun NGE tetap akan terikat pada norma hukum kebiasaan internasional dalam pertikaian bersenjata untuk melindungi kelompok yang rentan terhadap pelanggaran yang salah satunya adalah anak-anak.

\footnotetext{
${ }^{17}$ Ibid.

${ }^{18}$ Ibid.
} 


\section{b. Perlindungan Hak Anak dari Perekrutan Sebagai Tentara Anak dalam Konvensi Hak Anak.}

Konvensi Hak Anak (convention on the right of child) merupakan perjanjian internasional yang diadakan di bawah naungan Perserikatan Bangsa-Bangsa yang ditandatangani oleh negara-negara pada tahun 1989 Konvensi ini memperkenalkan prinsip-prinsip perlindungan anak yang terdiri dari prinsip prinsip non-diskriminsi, prinsip kepentingan terbaik bagi anak (the best interest of child), hak untuk hidup, kelangsungan hidup dan perkembangan, dan prinsip penghargaan terhadap pendapat anak.

Khusus berkaitan dengan perlindungan anak dalam konflik bersenjata ketentuan mengenai hal itu telah diatur secara khusus dalam Pasal 38 yang menyatakan $^{19}$ :

1) negara-negara peserta berupaya untuk menghormati dan menjamin penghormatan terhadap ketentuan-ketentuan hukum humaniter internasional yang berlaku bagi anak dalam konflik-konflik bersenjata;

2) negara-negara peserta akan mengambil semua langkah yang mungkin guna memastikan bahwa mereka yang belum mencapai usia lima belas tahun tidak terlibat secara langsung dalam permusuhan;

3) negara-negara peserta akan menahan diri untuk tidak merekrut orang yang belum mencapai usia lima belas tahun dalam angkatan bersenjata mereka. Dalam merekrut orang-orang yang sudah berusia lima belas tahun tetapi belum mencapai usia delapan belas tahun, negara-negara peserta akan berusaha untuk memberi prioritas kepada mereka yang tertua; dan

4) sesuai dengan kewajiban-kewajiban berdasarkan hukum kemanusiaan internasional untuk melindungi penduduk sipil dalam konflik-konflik bersenjata, negara-negara peserta akan mengambil semua langkah yang mungkin untuk menjamin perlindungan dan perawatan terhadap anakanak yang terkena akibat suatu konflik bersenjata.

Perlindungan anak dalam konvensi hak anak di atas merupakan adopsi ketentuan tentang perlindugan anak yang terdapat dalam protokol tambahan I dan II tahun 1977. Sebagaimana kebanyakan perjanjian internasional yang mengatur tentang HAM, konvensi hak anak hanya mengatur kepada perilaku negara dan berakibat hanya pada negara, daripada pihak yang terlibat dalam konflik yang tidak hanya negara, tetapi juga kelompok yang terlibat dalam konflik dengan negara. Manakala konflik bersenjata terjadi di luar pengaturan hukum humaniter internasional, maka akan menimbulkan masalah tersendiri dalam penerapan konvensi hak anak. ${ }^{20}$ Sebagai contoh, Guetamala telah menetapkan bahwa usia minimum seorang anak untuk

19 Pasal 38 Konvensi Hak Anak

${ }^{20}$ Ilene Cohen and Guy S Goodwin-ill, Child Soldiers Op.Cit, hlm. 69. 
direkrut sebagai tentara adalah 18 tahun, tetapi dalam kenyataanya masih banyak anak-anak yang direkrut dalam konflik bersenjata di bawah usia yang telah ditetapkan tersebut. Di sisi lain, Guetamala belum menjadi negara pihak (contracting parties) dalam konvensi hak anak. Hal ini kemudian menimbulkan masalah serius dalam penerapan dan kebijakan perlindungan hak anak.

Kondisi lain juga dapat terjadi dimana kelompok bersenjata yang terlibat dalam konflik bersenjata di mana hukum humaniter internasional tidak dapat diterapkan karena negaranya tidak menjadi negara pihak dalam protokol tambahan II dan menjadi pihak dalam konvensi hak anak seperti Sri Lanka, Peru, Sudan, dan Myanmar. Hal ini menimbulkan masalah yang cukup serius dalam penerapan perlindungan anak dari perekrutan anak dalam konflik bersenjata. ${ }^{21}$

\section{c. Perlindungan Hak Anak Dari Perekrutan Sebagai Tentara Anak dalam Protokol Pilihan terhadap Konvensi Hak Anak Berkaitan dengan Keterlibatan Anak dalam Konflik Bersenjata (The Optional ProtokolTo The Convention On The Rights Of The Child On The Involvement of Children In Armed Conflict).}

Protokol pilihan terhadap konvensi hak anak berkaitan dengan keterlibatan anak dalam konflik bersenjata lahir sebagai jawaban atas maraknya berbagai kegiatan perekrutan anak dalam konflik bersenjata di berbagai konflik besenjata di dunia. Pada tahun 2000 negara-negara menandatangani sebuah perjanjian internasional yang bersejarah sebagai usaha masyarakat internasional menghentikan aktivitas yang melanggar hak anak. Protokol tesebut akan mulai berlaku (entry into force) tiga bulan setelah diratifikasi oleh sepuluh negara. Sampai pada bulan 2004 terdapat 115 negara yang sudah menandatangani perjanjian ini dan telah diratifikasi oleh 71 negara.

Secara garis besar pengaturan perlindungan Hak Anak dari perekrutan sebagai tentara anak dalam protokol pilihan terbagi dalam beberapa bagian, yaitu: Partisipasi anak dalam konflik bersenjata (participation in hostilities), kewajiban negara untuk tidak mengikutsertakan anak-anak yang berusia di bawah 18 tahun sebagai tentara dalam konflik bersenjata (compulsory recruit/conscription), kewajiban bagi kelompok bersenjata non-pemerintah (non-governmental armed groups), perekrutan anak secara sukarela (voluntary recruitment), dan ketentuan lain yang berkaitan dengan implementasi, monitoring, dan ratifikasi protokol pilihan.

1) Partisipasi Anak dalam Konflik Bersenjata

21 Ibid. 
Protokol pilihan tersebut telah menyatakan secara tegas bahwa negara dilarang untuk mengikutsertakan anak di bawah umur 18 tahun sebagai batas umur minimum dalam keterlibatan anak dalam konflik bersenjata di negaranya. Ketentuan ini berlaku baik dalam partisipasi yang bersifat wajib (compulsory recruitment) maupun dalam setiap atau penggunaannya dalam pertikaian bersenjata yang yang dilakukan oleh kelompok bersenjata bukan pemerintah (non-governmental armed groups). Pasal 1 menyatakan bahwa "States Parties shall take all feasible measures to ensure that members of their armed forces who have not attained the age of 18 years do not take a direct part in hostilities". Lahirnya ketentuan ini menggantikan batasan umur yang dianut oleh negara selama ini yang tidak seragam yaitu diantara 15 sampai 18 tahun. Ketentuan ini juga memperkuat praktek negara selama ini yang menentukan usia minimum seseorang dalam keikutsertaannya dalam konflik bersenjata yaitu 18 tahun.

Menurut Daniel Helle, ${ }^{22}$ seorang penasehat hukum ICRC, kewajiban negara yang terdapat dalam Pasal 1 di atas memiliki dua kelemahan, yaitu: Pertama, sifat dari kewajiban negara tersebut merupakan salah satu bentuk tindakan semata, bukanlah hasil dari sebuah tindakan negara. Formulasi kewajiban negara yang hanya menekankan pada kewajiban untuk mengambil semua tindakan seperlunya (take all feasible measures to ensure) menyiratkan bahwa partisipasi anak dalam konflik bersenjata merupakan suatu hal tidak dapat diwujudkan. Kewajiban ini tidak ada bedanya dengan kewajiban yang lahir dalam protokol tambahan I Konvensi Jenewa 1949. Akan lebih baik jika ketentuan tersebut menurut Daniel Helle diubah menjadi kewajiban negara untuk mengambil segala tindakan yang diperlukan (take all necessary measures) dengan ketentuan tersebut tidak dimungkinkan lagi partisipasi anak dalam konflik bersenjata. Kedua, fokus dari pengaturan keterlibatan anak dalam konflik bersenjata hanya pada keterlibatan secara langsung anak dalam konflik bersenjata. Ketentuan pasal ini mengabaikan kenyataan bahwa keterlibatan anak dalam konflik bersenjata dapat pula berbentuk keterlibatan secara tidak langsung seperti anak berperan sebagai orang yang mencari informasi (gathering information), menyampaikan perintah (transmitting orders), membawa amunisi dan kebutuhan pangan prajurit (transporting ammunition and foodstuffs), atau tindakan sabotase (acts of sabotage). Keterlibatan anakanak dalam konflik bersenjata tersebut secara psikologis akan menimbulkan kerugian psikologis yang serius dan rasa trauma yang berkepanjangan. Keterlibatan langsung sebenarnya memiliki dampak yang sama dengan keterlibatan yang tidak langsung.

\footnotetext{
${ }^{22}$ Daniel Helle, Optional Protocol on the involment of children in armed conflict to the Convention on the Rights of the Child, (International Redcross Review, 2004), hlm. 15.
} 


\section{2) Perekrutan Wajib Tentara Anak (compulsorily recruit)}

Protokol pilihan juga mengatur hal yang berkaitan dengan kewajiban negara untuk tidak menjadikan orang yang belum berumur 18 tahun dalam perekrutan secara wajib sebagai tentara dalam angkatan bersenjata mereka. Pasal 2 secara lengkap menyatakan bahwa "States Parties shall ensure that persons who have not attained the age of 18 years are not compulsorily recruited into their armed forces". Kehadiran pasal ini dalam menentukan batas usia perekrutan tentara dalam angkatan bersenjata sebuah negara merubah secara fundamental praktek selama ini yang masih memberikan dua alternatif pilihan umur yaitu antara 15 sampai 18 tahun.

Pasal 2 menegaskan kembali kewajiban negara untuk melarang perekrutan anak yang belum usia 18 tahun sebagai tentara dalam sebuah pertikaian bersenjata. Dengan demikian, walaupun anak yang telah direkrut dan diterima dalam latihan militer mereka memiliki keterampilan dalam menghadapi musuh dalam sebuah konflik bersenjata, khususnya jika mereka menjadi bagian dari prajurit resmi sebuah negara.

Menurut Daniel Helle, antara hukum humaniter dan hukum HAM tidak memiliki kesamaan dalam menentukan batas umur seseorang dapat direkrut sebagai tentara. Hukum Humaniter sebagaimana diatur dalam opsional protokol I dan II masih mengakui umur 15 dan 18 tahun sedangkan Hukum HAM sebagaimana tertuang dalam opsional protokol terhadap konvensi hak anak berkaitan dengan keterlibatan anak dalam konflik bersenjata mengakui umur minimum untuk direkrut sebagai tentara adalah 18 tahun.

"...It is rightly observed that international humanitarian law, unlike human rights law, does not contain any definition of children, a fact that is attributable to the lack of a common understanding among delegates during earlier negotiations on the relevant age limit". ${ }^{23}$

Perbedaan batasan umur dalam menentukan usia minimum anak dalam kedua rezim hukum tersebut mencerminkan perbedaan pandangan dari para delegasi perunding negara dalam merumuskan naskah perjanjian internasional.

\section{3) Perekrutan Sukarela Tentara Anak}

Protokol Tambahan memungkinkan perekrutan tentara anak secara sukarela (voluntary recruitmen) oleh negara. Pemerintah harus menentukan bahwa perkerutan secara sukarela dilakukan terhadap anak yang berusia di luar dari 15 tahun. Dalam praktek menurut ICRC anak yang usia di luar 15 tahun adalah anak yang berusia 16 tahun. Negara yang melakukan

\footnotetext{
${ }^{23}$ Ibid.
} 
perekrutan sukarala harus menyampaikan deklarasinya kepada Sekretaris Jenderal PBB terkait dengan penentuan usia minimum yang dilakukannya.

Secara lengkap ketentuan pasal 3 menentukan sebagai berikut:

a) states Parties shall raise in years the minimum age for the voluntary recruitment of persons into their national armed forces from that set out in article 38, paragraph 3, of the Convention on the Rights of the Child, taking account of the principles contained in that article and recognizing that under the convention persons under the age of 18 years are entitled to special protection;

b) each state party shall deposit a binding declaration upon ratification of or accession to the present protokol that sets forth the minimum age at which it will permit voluntary recruitment into it's national armed forces and a description of the safeguards it has adopted to ensure that such recruitment is not forced or coerced.

Pasal 3 ayat (3) Protokol Pilihan menentukan syarat-syarat yang harus dipenuhi oleh pemerintah dalam merekrut secara sukarela anak-anak dalam konflik bersenjata yaitu :

States Parties that permit voluntary recruitment into their national armed forces under the age of 18 years shall maintain safeguards to ensure, as a minimum, that:

a) such recruitment is genuinely voluntary;

b) such recruitment is carried out with the informed consent of the person's parents or legal guardians;

c) such persons are fully informed of the duties involved in such military service; and

d) such persons provide reliable proof of age prior to acceptance into national military service.

Pemerintah yang merekrut tentara anak berusia di bawah 18 tahunharus mengambil tindakan perlindungan untuk memastikan bahwa anak-anak yang direkrut tersebut :

a) perekrutan tersebut dilakukan dengan sukarela atau tidak dengan paksaan;

b) dilakukan dengan persetujuan orang tua dari anak tersebut atau penasehat hukumnya ;

c) perkerutan itu bertujuan sebagai kewajiban dalam pelayanan dalam militer; dan

d) ditujukan dengan usia yang mencukupi dan anak tersebut diterima sebagai pelayanan militer nasional.

4) Perekrutan Tentara Anak oleh Kelompok Bersenjata non-Pemerintah

Kewajiban hukum untuk tidak merekrut anak di bawah 18 tahun sebagai tentara tidak saja ditujukan kepada angkatan bersenjata resmi 
pemerintah tetapi ditujukan pula kepada kelompok bersenjata nonpemerintah (armed groups distinct from the armed forces of a State). Pemerintah, di mana kelompok bersenjata non-pemerintah tersebut berada diwajibkan untuk mengkriminalisasikan (to criminalize) setiap perbuatan untuk merekrut anak di bawah 18 tahun sebagai tentara dan mengambil tindakan lain untuk mencegah perekrutan dan penggunaan anak sebagai tentara oleh kelompok bersenjata non-pemerintah tersebut. Secara lengkap Pasal 4 Protokol Pilihan menentukan sebagai berikut :

a) armed groups, distinct from the armed forces of a state, should not, under any circumstances, recruit or use in hostilities persons under the age of 18 years;

b) states parties shall take all feasible measures to prevent such recruitment and use, including the adoption of legal measures necessary to prohibit and criminalize such practices; and

c) the application of the present article under this Protokol shall not affect the legal status ofany party to an armed conflict.

Larangan untuk merekrut tentara anak oleh kelompok bersenjata bukan pemerintah ditujukan baik perekrutan yang bersifat wajib atau bersikap sukarela dalam sebuah konflik bersenjata, baik partisipasi langsung maupun tidak langsung.

Ketentuan yang terdapat dalam Pasal 4 Protokol tambahan merupakan indikasi positif dari keinginan negara-negara mengatur perilaku dari entitas non negara dalam konflik bersenjata, ketentuan tersebut ditujukan kepada konflik bersenjata yang bersifat non internasional. Larangan pengaturan tersebut merupakan inisiatif dari ICRC sebagai organisasi internasional yang memiliki konsen terhadap masalah kemanusiaan dalam konflik bersenjata. Perhatian tersebut didasarkan pada kenyataan bahwa keterlibatan anak dalam konflik bersenjata dapat menimbulkan trauma dan kematian bagi anak.

Menurut David Hell, ketentuan dalam Pasal 4 telah dirancang untuk menjamin kepastian adanya tindakan efektif untuk mencegah perekrutan dan partisipasi anak dalam konflik bersenjata dalam negeri. Kesungguhan ketentuan tersebut dapat dilihat dari formulasi norma yang ada dalam Pasal 4 Konvensi yang membebankan kewajiban bagi kelompok bersenjata nonpemerintah dengan kata "should not", bukan kata "shall not" yang dalam hukum internasional merupakan pembebanan kewajiban hukum daripada kewajiban moral. Pemilihan kata tersebut untuk memangkas praktek selama ini di mana negara saja yang dibebankan kewajiban hukum dalam hukum HAM internasional. Sedangkan entitas bukan negara diwajibkan berdasarkan pada hukum nasional.

"In this regard, the wording chosen seems to be motivated by the concern of many States not to depart from the classical approach of international human rights law, according to which the broad 
rule is that only States have an obligation under human rights law, whereas the behaviour of non-State entities is to be regulated by domestic law ${ }^{\text {'22 }}$

Kriminalisasi perekrutan tentara anak dalam hukum nasional memiliki dampak dapat menimbulkan efek jera (detterent effect) dalam mencegah terjadinya tindak pidana tersebut. Hal ini di dasarkan pada dua hal, yaitu : Pertama, pihak yang berkonflik dengan pemerintah yang sah telah mengikrarkan diri mereka telah melakukan pelanggaran hukum, sehingga mereka dapat dengan mudah dinyatakan melanggar hukum. Kedua, kemampuan pemerintah untuk menegakkan hukum nasionalnya sangat terbatas dalam banyak kasus konflik bersenjata non-internasional kontemporer. $^{25}$

\section{d. Perlindungan Hak Anak dari Perekrutan Sebagai Tentara Anak} dalam ILO Convention No. 182 Concerning The Prohibition and Immediate Action for The Elimination of The Worst Forms of Child Labour (Konvensi ILO 182 tentang Bentuk Pekerjaan Terburuk Terhadap Anak).

Perlindungan hak anak dari perekrutan sebagai tentara anak dapat dilihat dari aspek perburuhan. Karena pada dasarnya mengikutsertakan anak dalam konflik bersenjata berarti mempekerjakan anak dalam suatu pekerjaan tertentu. Masyarakat internasional melalui Organasi Perburuhan Internasional (International Labour Organization) menaruh perhatian pula terhadap masalah perekrutan tentara anak. Perlindungan ini dikaitkan dengan hak seorang anak untuk tidak melakukan pekerjaan yang secara psikis dan fisik belum mampu melakukannya.

Pada tanggal 17 Juni 1999 negara-negara anggota ILO telah menandatangani Konvensi Bentuk Pekerjaan Terburuk Terhadap Anak (Worst Forms of Child Labour Convention 182), dan mulai berlaku sejak tanggal 19 November 2000. Perjanjian internasional tersebut mewajibkan bagi negara yang meratifikasinya untuk mengambil tindakan mendesak dan efektif untuk melarang dan mengeliminasi terjadinya berbagai bentuk pekerjaan terburuk bagi anak (take immediate and effective measures to secure the prohibition and elimination of the worst forms of child labor as a matter ofurgency).Batasan anak yang terdapat dalam Konvensi ILO tersebut adalah orang yang belum berumur 18 Tahun. Batasan umur tersebut rupanya mengikuti batasan umur yang dianut dalam Konvensi Hak Anak maupun dalam Protokol Pilihan di atas.

\footnotetext{
24 Ibid.

${ }^{25}$ Ibid.
} 
Bentuk pekerjaan terburuk terhadap anak menurut Pasal 22 ayat (2) Konvensi ILO adalah : "all forms of slavery or practices similar to slavery, such as the sale and trafficking of children, debt bondage and serfdom and forced or compulsory labour, including forced or compulsory recruitment of children for use in armed conflict". Batasan tersebut menjelaskan bahwa yang termasuk pekerjaan terburuk terhadap anak adalah semua bentuk perbudakan (slavery) ataupun pekerjaan yang menyerupai perbudakan, seperti penjualan dan perdagangan anak (sale and trafficking of children), pemaksaan menjadi buruh, termasuk pula perekrutan secara paksa anak untuk digunakan dalam konflik bersenjata.Katagori bentuk pekerjaan terburuk yang terakhir di atas bila kita bandingkan dengan pengaturan dalam beberapa konvensi di atas merupakan kategori penggunaan anak sebagai tentara dalam konflik bersenjata baik internasional maupun nasional.

Konvensi ILO mewajibkan negara pihak dalam konvensi untuk menentukan bahwa perbuatan untuk memperkerjakan anak-anak untuk digunakan dalam konflik bersenjata sebagai sebuah tindak pidana (criminal offence). Kewajiban itu memiliki kesamaan dengan ketentuan yang terdapat dalam Protokol Tambahan di atas yang mengkriminalisasi perbuatan merekrut anak di bawah 18 tahun oleh kelompok bersenjata di negaranya sebagai sebuah kejahatan. Ketentuan ini merupakan pengakuan hukum secara khusus bahwa perekrutan tentara anak sebagai bentuk pekerjaan anak yang terburuk.

Konvensi ILO juga melarang bentuk pekerjaan dan sifat atau karena keadaan dapat merusak kesehatan, keselamatan, dan moral anak. Pelarangan itu dapat dilakukan dalam hukum nasional setelah dilakukan konsultasi asosiasi buruh di negaranya, termasuk untuk menentukan hal apa saja yang dapat dilarang.

\section{e. Perlindungan Hak Anak dari Perekrutan Sebagai Tentara Anak dalam Statuta Pengadilan Pidana Internasional (International Criminal Court).}

Pengadilan Pidana Internasional (International Criminal Court/ICC) adalah organisasi internasional yang didirikan oleh negara-negara pada tahun 1998 melalui sebuah perjanjian internasional. Kehadiran ICC merupakan sebuah komitmen baru dari masyarakat internasional untuk memerangi kejahatan serius dan menjadi perhatian masyarakat internasional (the most serius crime of concerns to the international community as a whole). ${ }^{26}$ Pengadilan Pidana internasional memiliki yurisdiksi pada empat jenis kejahatan yaitu : Genosida (genocida), kejahatan terhadap kemanusiaan

\footnotetext{
${ }^{26}$ Ibid.
} 
(crimes against humanity), kejahatan perang (war crimes), dan Agresi (aggression).

Yurisdiksi ICC di atas, tidaklah berlaku secara otomatis sebagaimana pengadilan pidana nasional yang dapat langsung menerapkan yurisdiksi di wilayah teritorialnya, tetapi bersifat komplementer. Untuk dapat dilaksanakannya yurisdiksi ICC harus dipenuhi dua persyaratan, yaitu ${ }^{27}$ :

1) jika yurisdiksi pengadilan nasional tidak menunjukkan keinginan (unwillingness) untuk melakukan kejahatan serius tersebut; dan

2) jika yurisdiksi pengadilan nasional tidak memiliki kemampuan (inability) untuk melaksanakan peradilan terhadap kejahatan serius tersebut.

Perlindungan hak anak dari perekrutan sebagai tentara anak diatur dalam Pasal 8 huruf (e) angka (vii) Statuta. Dalam ketentuan tersebut, menyatakan bahwa salah satu unsur dari kejatahan perang (war crimes) yang merupakan yurisdiksi ICC adalah perekrutan anak yang berusia di bawah 15 tahun sebagai tentara. Pasal 8 huruf (e) angka (vii) Statuta menentukan bahwa salah satu unsur dari kejahatan perang adalah :

"Other serius violations of laws and customs applicable in armed conflicts not international character, within the established frame work of international law, namely, any of the following acts $\therefore . .$. (vii) conscripting or enlisting children under the age of fifteen years into armed groups or using them to participate actively in hostilities"

Terminologi Perekrutan anak yang berusia di bawah 15 tahun sebagai tentara anak dalam ketentuan Statuta Roma di atas menggunakan istilah conscripting or enlisting. Kedua istilah tersebut sebenarnya memiliki makna yang sama dengan istilah recruitment sebagaimana tertuang dalam Protokol Tambahan dan Konvensi Hak Anak, yaitu perekrutan anak dalam konflik bersenjata.

\section{Pengaturan Perekrutan Anak dalam Konflik Bersenjata di Indonesia}

Politik perundang-undangan Indonesia terkait dengan hak-hak anak dilakukan dengan progresif melalui pengesahan berbagai perjanjian internasional dan pembentukan hukum nasional Indonesia. Pengesahsan perjanjian internasional dilakukan melalui kebijakan pada tahun 1990 pemerintah melalui Keppres No. 36 tahun 1990 tentang pengesahan Konvensi Hak Anak (convention on the right of the child). Pada tahun 2012 pemerintah mengambil kebijakan meratifikasi Protokol Opsional Konvensi Hak-Hak Anak Mengenai Keterlibatan Anak dalam Konflik Bersenjata melalui Undang-Undang Nomor 12 Tahun 2012.

\footnotetext{
${ }^{27}$ Romli Atmasasmita, Pengantar...Op.Cit, hlm. 50.
} 


\section{a. Pengesahan Perjanjian Internasional di Bidang Perlindungan Anak}

Pengesahan instrumen hukum internasional Indonesia berimplikasi keterikatan diri Indonesia untuk taat pada perjanjian internasional yang telah diratifikasinya. Hal ini sesuai dengan prinsip pacta sunt servanda dalam hukum perjanjian internasional. ${ }^{28}$ Hukum Internasional yang telah diratifikasi harus dianggap merupakan bagian dari hukum nasional Indonesia, oleh karenanya hukum nasional yang mengatur tentang hak anak harus disesuaikan dengan instrumen hukum internasional yang telah diratifikasi Indonesia tersebut. ${ }^{29}$ Dengan demikian perjanjian internasional di bidang perlindungan anak dari perekrutan sebagai tentara anak adalah bagian dari hukum nasional Indonesia.

Pengaturan tentang perlindungan hak anak dari perekrutan sebagai kombatan memiliki kesamaan dengan pengaturan sebagaimana telah diuraikan di atas. Untuk itu, untuk menghindari pengulangan penulis tidak akan menguraikannya kembali. Hal yang penting bagi Indonesia dalam konteks meratifikasi konvensi hak anak tersebut dalam memikirkan implikasi yang lahir dari ratifikasi itu. Hak dan kewajiban apa yang lahir dari ratifikasi kovenan hak anak tersebut bagi penyesuaian aturan hukum nasional Indonesia. Serta bagaimana pula kedudukan ratifikasi melalui instrumen Keputusan Presiden terhadap dibentuknya instrumen hukum yang mengatur tentang hak anak pada waktu yang akan datang?

Sebagaimana diuraikan di atas kita telah meratifikasi kovenan hak anak melalui instrumen keputusan Presiden. Instrumen ini menurut hemat penulis memiliki implikasi hukum tersendiri dalam sistem perundangundangan nasional Indonesia sekarang ini, karena terjadinya perubahan fundamental terkait hal-hal yang berhubungan dengan mekanisme ratifikasi yang diatur dalam Undang-Undang Nomor 24 Tahun 2000 tentang Perjanjian Internasional dan tata urutan peraturan perundang-undangan yang diatur dalam Undang-Undang Nomor 10 Tahun 2004 tentang tata cara pembentukan peraturan perundang-undangan.

Dari sisi ratifikasi perjanjian internasional mekanisme ratifikasi perjanjian internasional saat ini telah berubah secara signifikan dibanding dengan sebelumnya. Pasca berlakunya Undang-Undang Perjanjian Internasional telah diperjelas persoalan yang diratifikasi melalui undangundang maupun melalui Keputusan Presiden. Ratifikasi perjanjian internasional yang memerlukan undang-undang adalah hal-hal sebagai berikut:

\footnotetext{
${ }^{28}$ Budiono Kusumahadijojo, Suatu Studi terhadap aspek operasional Konvensi Wina Tahun 196 tentang Hukum Perjanjian Internasional, (Bandung: Binacipta, 1985), hlm.15. lihat juga L.Oppenhaim, International Law: a Treatise, $8^{\text {th }}$ edition, 1961 cetakan ke-5 hlm.880.

${ }^{29}$ Harjono, Politik Hukum Perjanjian Internasional, (Surabaya: Bina Ilmu, 1999), hlm.131.
} 
1) masalah politik, perdamaian, pertahanan, dan keamanan negara;

2) perubahan wilayah atau penetapan batas wilayah negara Republik Indonesia;

3) kedaulatan dan hak berdaulat Negara;

4) hak asasi manusia dan lingkungan hidup;

5) pembentukan kaidah hukum baru; dan

6) pinjaman dan/atau hibah luar negeri.

Sedangkan hal-hal yang di luar persoalan di atas diratifikasi melalui instrumen Keputusan Presiden. Jika kita lihat ketentuan yang berkaitan dengan perlindungan anak maka ketentuan dalam konvensi tersebut mengatur tentang HAM dan membentuk norma hukum yang baru. Maka seharusnya ketika meratifikasi konvensi ini pemerintah melakukannya dengan instrumen undang-undang. Dalam kenyataannya hal ini dilakukan dengan instrumen Keppres. Persoalan ini akan membawa implikasi pada waktu yang akan datang manakala pemerintah dan DPR hendak membentuk Undang-Undang yang mengatur persoalan yang berhubungan dengan perlindungan hak anak. Pemerintah tidak dapat merujuk Kovenan Hak Anak sebagai salah satu sumber hukum karena kedudukannya yang lebih rendah dalam hierarki peraturan perundang-undangan Indonesia. ${ }^{30}$

Hal lain yang menjadi persolan terkait dengan Keputusan Presiden No.36 Tahun 1990 tentang pengesahan Konvensi Hak Anak (convention on the right of the child) adalah substansi hukum yang dapat diatur dalam keputusan Presiden. Dalam sistem perundang-undangan Indonesia yang baru keputusan presiden tidak dimungkinkan lagi untuk memasuki wilayah pengaturan terhadap hal-hal yang berkaitan dengan sifat regulatif. Keputusan presiden dalam konteks perundang-undang saat ini diperbolehkan hanya mengatur hal-hal yang berkaitan dengan keputusan yang bersifat beschiking bukan lagi regeling. ${ }^{31}$ Sehingga kovenan hak anak yang pada umumnya bersifat regulatif dan menimbulkan dampak hukum yang luar biasa bagi negara harus diatur melalui undang-undang. ${ }^{32}$

Kebijakan meratifikasi Protokol Opsional Konvensi Hak-Hak Anak Mengenai Keterlibatan Anak dalam Konflik Bersenjata melalui Undang-

30 Pasal 7 UU No.10 Tahun 20004 tentang Tata Cara Pembentukan Peraturan Perundang Undangan menentukan hierarki peraturan perndang-undangan nasional yaitu : 1.UUD 1945;

2.Undang-undang/Perpu ;

3.Peraturan Pemerintah ;

4.Peraturan Presiden ;

5.Peraturan Daerah.

31 Jimly Asshiddiqy, Hukum Acara Pengujian Peraturan Perundang-Undangan, (Jakarta: Konstitusi Press, 2006), hlm. 25.

32 Jimly Asshiddiqy, Perihal Undang-undang, (Jakarta: Konstitusi Press, 2006), hlm. 229230. 
Undang Nomor 12 tahun 2012 didasarkan pada pertimbangan untuk memperkuat komitmen Indonesia dalam upaya perlindungan terhadap anak yang terlibat dalam konflik bersenjata yang telah ditandatangani oleh Pemerintah pada tanggal 24 September 2001 yang merupakan salah satu bagian yang tidak terpisahkan dari Convention on the Rights of the Child (Konvensi tentangHak-Hak Anak) sebagai hasil Sidang Majelis Umum Perserikatan Bangsa-Bangsa yang diterima pada tanggal 20 November 1989.

Hal terpenting dalam protokol pilihan ini adalah pengaturan tentang kewajiban-kewajiban hukum bagi negara pihak dalam implementasi konvensi yaitu:

1) mengambil langkah-langkah yang memungkinkan untuk memastikan bahwa anggota dari angkatan bersenjata yang belum berumur 18 tahun tidak dilibatkan secara langsung dalam peperangan;

2) menaikan batas usia minimum perekrutan sukarela dalam angkatan bersenjata nasional dengan mempertimbangkan prinsip pada Konvensi Hak-hak Anak dan Protokol Opsional ini;

3) memastikan bahwa orang yang belum berusia 18 tahun tidak direkrut dalam wajib militer;

4) mengambil langkah-langkah untuk mencegah, melarang, dan mengkriminalisasi kelompok bersenjata yang bukan bagian dari angkatan bersenjata nasional dalam keadaan apapun untuk merekrut atau menggunakan anak di bawah usia 18 tahun untuk dilibatkan dalam konflik bersenjata;

5) mengambil langkah-langkah administratif dan tindakan lainnya yang diperlukan untuk mengefektifkan pelaksanaan dan penegakan ketentuan yang diatur dalam Protokol Opsional ini;

6) mengambil semua langkah yang memungkinkan untuk menjamin bahwa orang di dalam yurisdiksi mereka direkrut atau digunakan dalam peperangan yang bertentangan dengan Protokol Opsional ini untuk didemobilisasi atau dibebastugaskan;

7) menjalin kerja sama antar Negara-Negara Pihak, termasuk kerja sama teknik dan bantuan finansial, dalam melaksanakan Protokol Opsional ini, termasuk dalam pencegahan terhadap semua kegiatan yang bertentangan dengan Protokol Opsional, serta di bidang rehabilitasi dan reintegrasi sosial bagi korban; dan

8) menyerahkan dalam dua tahun setelah berlakunya Protokol Opsional, informasi yang komprehensip dan tindakan-tindakan yang diambil untuk mengimplementasikan Protokol Opsional.

Ketika meratifikasi Protokol Opsional pemerintah Indonesia mengambil kebijakan untuk melakukan deklarasi terhadap ketentuan pasal 3 ayat (2) Protokol Opsional dengan menyatakan, bahwa : Pertama, Usia minimum untuk rekrutmen sukarela menjadi prajurit Tentara Nasional 
Indonesia adalah 18 tahun. Lebih lanjut, Pasal 28 ayat (1) d Undang-Undang Nomor 34 Tahun 2004 tentang Tentara Nasional Indonesia mengatur bahwa "pada saat dilantik menjadi prajurit berumur paling rendah 18 (delapan belas) tahun". Kedua, Rekrutmen untuk menjadi anggota Tentara Nasional Indonesia adalah sungguh-sungguh bersifat sukarela. Rekrutmen dilakukan secara terbuka dan pemberitahuannya kepada publik dilakukan dengan memanfaatkan berbagai sarana teknologi informasi dan komunikasi. Rekrutmen mensyaratkan antara lain adanya bukti akta kelahiran dan persetujuan orang tua atau wali yang sah, termasuk bagi mereka yang telah berusia 18 tahun.

\section{Pengaturan Perekrutan Anak dalam Peraturan Perundang- Undangan Nasional}

Pengaturan khusus yang berhubungan dengan perlindungan hak anak dari perekrutan sebagai tentara anak dalam Undang-Undang HAM diatur dalam Pasal 63 dan 64. Pasal 63 menentukan bahwa:

"Setiap anak berhak untuk tidak dilibatkan di dalam peristiwa peperangan, sengketa bersenjata, kerusuhan sosial, dan peristwa lain yang mengandung unsur kekerasan".

Pengaturan perlindungan anak pada Pasal 64 di atas menunjukkan perlindungan yang maksimal terhadap anak. Perlindungan hak anak dalam UU HAM ini melebihi perlindungan yang terdapat dalam konvensi internasional yang hanya memberikan perlindungan anak untuk tidak dilibatkan dalam konflik bersenjata hanya pada peristiwa peperangan dan sengketa bersenjata. Sedangkan Pasal 4 UU HAM di atas mencakup juga perlindungan anak ketika terjadinya konflik horizontal dalam masyarakat dan peristiwa lain yang mengandung unsur kekerasan.

Pasal 64 perlindungan anak dari perekrutan sebagai tentara anak dihubungkan dengan pekerjaan yang terburuk bagi anak.

"Setiap anak berhak untuk memperoleh perlindungan dari kegiatan eksploitasi ekonomi dan setiap pekerjaan yang membahayakan dirinya, sehingga dapat mengganggu pendidikan, kesehatan fisik, moral, kehidupan sosial, dan mental spiritualnya".

Ketentuan yang terdapat dalam Pasal 64 di atas bila dihubungkan dengan aspek perlindungan hak anak dari perekrutan sebagai tentara anak maka perlindungan yang dikehendaki adalah perlindungan anak dari pekerjaan terburuk yang dapat membahayakan dirinya. Pekerjaan tersebut tidak hanya mengganggu anak dari sisi fisik semata tetapi, dapat membahayakan pendidikan, moral, kehidupan sosial, dan spiritualnya. Dengan demikian, anak yang direkrut dalam konflik bersenjata, jika tidak dilindungi maka akan berpotensi merusak kesehatan fisik pendidikan, moral, kehidupan sosial, dan spiritualnya. Oleh karena itu, negara harus menjamin 
adanya perlindungan anak untuk tidak dilibatkan dalam konflik bersenjata, karena secara hukum perbuatan tersebut dapat melanggar hak anak.

Diundangkannya Undang-Undang Nomor 23 Tahun 2002 di dasarkan pada landasan filosofis bahwa anak merupakan anugerah Tuhan Yang Maha Kuasa kepada manusia yang harus dilindungi. Di samping itu, sebagai manusia anak memiliki hak yang sama dengan manusia dewasa. Bahkan secara psikologis dan fisik anak mendapatkan perlakuan khusus dibandingkan orang dewasa. Oleh karena itu, negara harus memberikan perlindungan yang maksimal dalam melindungi hak anak.

Secara sosiologis anak adalah penerus generasi bangsa yang akan melanjutkan kehidupan berbangsa dan bernegara. Anak adalah calon pemimpin masa depan yang menentukan arah kehidupan berbangsa dan bernegara pada masa yang akan datang. Jika anak tidak dilindungi hak-hak asasinya sejak dini, maka akan membahayakan kondisi kehidupan berbangsa dan bernegara pada masa yang akan datang. Merupakan sebuah kenyataan pula selama ini terjadi pelanggaran hak anak baik yang dilakukan oleh negara membiarkan kondisi terjadinya pelanggaran hak anak. Contoh yang paling mutakhir adalah dipraktekannya pekerja anak dalam berbagai industri dan terjadinya kekerasan pada anak yang sangat memprihatinkan.

Dari sisi yuridis merupakan norma hukum yang mengatur tentang perlindungan anak dalam hukum nasional masih sangat minim. Walaupun telah diatur dalam Undang-Undang HAM namun, pengaturannya masih belum memadai akan kebutuhan perlindungan anak yang begitu luas dan kompleks. Di samping itu, secara yuridis Indonesia telah terikat secara hukum dalam berbagai perjanjian internasional yang berkaitan dengan perlindungan anak. Pada tahun 1999 melalui Undang-Undang Nomor 20 Tahun 1999 tentang Pengesahan ILO Convention No. 138 Concerning Minimum Age for Admission to Employment (Konvensi ILO mengenai Usia Minimum untuk Diperbolehkan Bekerja) (Lembaran Negara Tahun 1999 Nomor 56, Tambahan Lembaran Negara Nomor 3835), setahun kemudian, pada tahun 2000 Indonesia melalui Undang-Undang Nomor 1 Tahun 2000 telah meratifikasi ILO Convention No. 182 Concerning The Prohibition and Immediate Action for The Elimination of The Worst Forms of Child Labour (Konvensi ILO No. 182 mengenai Pelarangan dan Tindakan Segera Penghapusan Bentuk-Bentuk Pekerjaan Terburuk Untuk Anak) (Lembaran Negara Tahun 2000 Nomor 30, Tambahan Lembaran Negara Nomor 3941).

Ratifikasi kedua perjanjian internasional di atas membawa implikasi hukum bagi Indonesia sebagai negara pihak untuk melakukan implementasi ketentuan perjanjian internasional di atas dalam hukum nasionalnya. Undang-Undang Nomor 23 Tahun 2002 dengan demikian harus merujuk kepada ketentuan kedua konvensi di atas. 
Definisi tentang anak dalam UU Perlindungan anak merupakan pengadopsian ketentuan yang terdapat dalam Pasal 1 UU HAM, yaitu setiap manusia yang berusia di bawah 18 (delapan belas) tahun dan belum menikah, termasuk anak yang masih dalam kandungan apabila hal tersebut adalah demi kepentingannya. Penentuan kategori usia anak sampai dengan 18 (delapan belas) tahun merupakan pengadopsian ketentuan hukum yang ada dalam konvensi ILO di atas.

Pasal 15 mengatur perlindungan secara khusus terhadap anak dalam kegiatan-kegiatan yang rentan penggunaan anak. Untuk itu anak-anak dilindungi dari penyalahgunaan kegiatan politik, perlibatan dalam sengketa bersenjata, perlibatan dalam kerusuhan sosial, perlibatan dalam peristiwa yang mengandung unsur kekerasan, dan perlibatan dalam peperangan. ${ }^{33}$

Pasal 59 juga mengatur ketentuan yang berkaitan dengan perlindungan anak dalam keadaan darurat. Ketentuan lebih lanjut tentang perlindungan anak dalam keadaan darurat diatur secara terperinci dalam Pasal 60 yang menyatakan bahwa anak dalam keadaan darurat yang dimaksud dalam Pasal 59 adalah anak : anak yang menjadi pengungsi; anak korban kerusuhan; anak korban bencana alam; dan anak dalam situasi konflik bersenjata. Pasal 69 Undang-Undang Perlindungan Anak menentukan bahwa perlindungan khusus terhadap anak yang menjadi pengungsi mengikuti ketentuan hukum humaniter. Dirujuknya hukum humaniter sebagai ketentuan hukum yang mengatur anak sebagai pengungsi menunjukkan bahwa anak dalam konflik bersenjata harus diposisikan sebagai kelompok masyarakat sipil yang harus dilindungi sebagaimana ketentuan yang terdapat dalam common articles dalam Pasal 3 dari Konvensi Jenewa 1949.

Selain itu dirujuknya hukum humaniter sebagai landasan hukum untuk mengatur anak sebagai pengungsi menurut hemat kami hanya merujuk pada Konvensi Jenewa yang telah dratifikasi Indonesia. Sebagaimana diketahui Indonesia telah mengesahkan keikutsertaannya dalam keempat Konvensi Jenewa 1949 dengan cara akses melalui Undang-Undang Nomor 59 Tahun 1958. Dengan demikian Indonesia secara hukum memiliki kewajiban untuk taat dan melaksanakan ketentuan empat Konvensi Jenewa tersebut.

Pasal 62 menentukan bentuk perlindungan khusus terhadap anak yang menjadi korban kerusuhan, bencana alam dan anak dalam situasi konflik bersenjata dengan bentuk perlindungan, yaitu :

a. pemenuhan kebutuhan dasar yang terdiri atas pangan, sandang, pemukiman, pendidikan, kesehatan, belajar dan berekreasi, jaminan keamanan, dan persamaan perlakuan; dan

b. pemenuhan kebutuhan khusus bagi anak yang menyandang cacat dan anak yang mengalami gangguan psikososial.

\footnotetext{
${ }^{33}$ Pasal 15 UU Perlindungan Anak.
} 
Khusus yang berkaitan dengan perlindungan hak anak dari perekrutan sebagai tentara dalam konflik bersenjata, diatur secara khusus dalam Pasal 63 yang menentukan bahwa "setiap orang dilarang merekrut atau memperalat anak untuk kepentingan militer dan/atau lainnya dan membiarkan anak tanpa perlindungan jiwa". Bentuk pengaturan dalam Pasal 63 ini merupakan kriminalisasi perbuatan perekrutan tentara anak. Perbuatan tersebut dianggap sebagai kejahatan.

Untuk memperkuat ketentuan yang terdapat dalam Pasal 63 maka dalam Pasal 83 ditentukan bentuk ancaman pidana yang dapat diterapkan terhadap pelaku perekrut anak dalam konflik bersenjata. Selengkapnya Pasal 83 menentukan :

"Setiap orang yang secara melawan hukum merekrut atau memperalat anak untuk kepentingan militer sebagaimana dimaksud dalam Pasal 63 atau penyalahgunaan dalam kegiatan politik atau perlibatan dalam sengketa bersenjata atau perlibatan dalam kerusuhan sosial atau perlibatan dalam peristiwa yang mengandung unsur kekerasan atau perlibatan dalam peperangan sebagaimana dimaksud dalam Pasal 15 dipidana dengan pidana penjara paling lama 5 (lima) tahun dan/atau denda paling banyak $\mathrm{Rp}$ 100.000.000,00 (seratus juta rupiah)".

Kriminalisasi perekrutan anak dalam konflik bersenjata pada ketentuan di atas menunjukkan bahwa adanya semangat dan ketentuan yang sama sebagaimana terdapat dalam protokol pilihan pada konvensi hak anak yang mewajibkan negara untuk melakukan kriminalisasi terhadap perbuatan merekrut anak dalam konflik. Kewajiban itu tidak hanya ditujukan kelompok bersenjata non-pemerintah, tetapi juga kepada kelompok militer resmi pemerintah seperti Tentara Nasional Indonesia.

Undang-Undang Nomor 34 Tahun 2004 tentang Tentara Nasional Indonesia memiliki kaitan dengan aspek perlindungan hak anak dalam konflik bersenjata. Keterkaitan tersebut karena dalam Undang-Undang TNI yang berlaku sekarang menentukan dua jenis prajurit TNI yaitu: prajurit sukarela dan prajurit wajib. Di samping itu, Undang-Undang TNI juga mengatur persyaratan umur menjadi TNI, yang memiliki kaitan dengan metode keterlibatan anak dalam konflik bersenjata.

Pasal 22 Undang-Undang TNI menentukan bahwa Prajurit TNI terbagi dalam dua kelompok yaitu: prajurit wajib dan prajurit sukarela. Prajurit Sukarela adalah warga negara yang atas kemauan sendiri mengabdikan diri dalam dinas keprajuritan. ${ }^{34}$ Sedangkan Prajurit Wajib adalah warga negara yang mengabdikan diri dalam dinas keprajuritan karena

\footnotetext{
${ }^{34}$ Pasal 1 angka 15 UU No. 34 tahun 2004 tentang TNI.
} 
diwajibkan berdasarkan peraturan perundang-undangan. ${ }^{35}$ Prajurit wajib menjalani dinas keprajuritan berdasarkan ikatan dinas, sedangkan prajurit sukarela menjalani dinas keprajuritan dengan ikatan dinas. Pembentuk undang-undang rupanya membedakan dua jenis prajurit merujuk kepada praktek negara-negara dan konvensi internasional yang membagi cara perekrutan anak dalam konflik bersenjata dalam dua kelompok yaitu prajurit sukarela (voluntary recruitment) dan prajurit wajib (compulsory recruitment).

Ketentuan penting lainnya yang berhubungan dengan perlindungan anak dalam konflik bersenjata adalah ketentuan tentang persyaratan menjadi anggota TNI. Pasal 28 tentang persyaratan menjadi prajurit TNI, yaitu :

a. warga negara Indonesia;

b. beriman dan bertakwa kepada Tuhan Yang Maha Esa;

c. setia kepada Negara Kesatuan Republik Indonesia yang berdasarkan Pancasila dan Undang-Undang Dasar Negara Republik Indonesia Tahun 1945;

d. pada saat dilantik menjadi prajurit berumur paling rendah 18 tahun;

e. tidak memiliki catatan kriminalitas yang dikeluarkan secara tertulis oleh Kepolisian Negara Republik Indonesia;

f. sehat jasmani dan rohani;

g. tidak sedang kehilangan hak menjadi prajurit berdasarkan putusan pengadilan yang telah memperoleh kekuatan hukum tetap;

h. lulus pendidikan pertama untuk membentuk prajurit siswa menjadi anggota TNI; dan

i. persyaratan lain sesuai dengan keperluan.

Persyaratan penting yang berhubungan dengan perlindungan hak anak adalah penentuan usia minimum anak yang dapat menjadi menjadi prajurit. Pasal 28 di atas menentukan bahwa persyaratan umur minimum untuk menjadi prajurit TNI adalah berumur minimal 18 (delapan belas) tahun. Persyaratan minimum umur tersebut jika kita perhatikan selaras dengan praktek umum perekrutan tentara yang dilakukan oleh negara-negara lain, dan ketentuan konvensi internasional yang menentukan usia minimal 18 (delapan belas) tahun sebagai syarat untuk menjadi anggota angkatan bersenjata yang berhak terlibat dalam konflik bersenjata.

\section{Penutup}

Persoalan perekruatan anak dalam konflik bersenjata akan bersentuhan dengan beberapa rezim Hukum Internasional : Hukum Humaniter Internasional, Hukum HAM Internasional, Hukum Pidana Internasional, dan Hukum Ketenagakerjaan Internasional. Pengaturan dalam berbagai rezim

35 Pasal 1 angka 16 UU No. 34 tahun 2004 tentang TNI. 
hukum tersebut masih menyisakan permasalahan terkait dengan : pertama, tidak ada keseragaman tentang usia minimum anak yang dapat direkrut sebagai anak apakah 15 tahun atau 18 tahun? kedua, kewajiban-kewajiban hukum bagi negara tidak memiliki kekuatan hukum yang sama antara kewajiban yang bersifat menyerukan saja kepada negara atau kewajiban yang bersifat wajib (compulsory obligation).

\section{Daftar Pustaka}

Asshiddiqie, Jimly, 2006. Hukum Acara Pengujian Peraturan PerundangUndangan, Jakarta: Konstitusi Press. , 2006, Perihal Undang-undang, Jakarta: Konstitusi Press.

Atmasasmita, Romli, 2004. Pengantar Hukum Pidana Internasional, Bandung: Hecca Mitra Utama.

Cohen, Ilene and Guy S. Goodwin-Gill, 1997. Soldiers: The Role of Children in Armed Conflict, Oxford: Clarendon Press.

Dutli, M.T., 1990. Captured Child Combatant, International Review of the Red Cross.

Harjono, 1999. Politik Hukum Perjanjian Internasional, Surabaya: Bina Ilmu.

Helle, Daniel, 2004. Optional Protocol on the involment of children in armed conflict to the Convention on the Rights of the Child, International Redcross Review.

Kalsoven, Frits dan Leisbeth Zegveld, 2001. Constraints on Waging of The War: An Introduction to International Humanitarian Law, ICRC.

Kusumahadijojo, Budiono, 1985. Suatu Studi terhadap aspek operasional Konvensi Wina Tahun 196 tentang Hukum Perjanjian Internasional, Bandung: Binacipta.

Oppenhaim, L., 1961. International Law: a Treatise, $8^{\text {th }}$ edition.

Rizki, Rudi M., 2004. Kekerasan Seksual Terhadap Perempuan di Daerah Konflik : Peluang Pertanggungjawabanya di Indonesia, Jurnal PAHAM, Edisi Kedua Desember 2004, Bandung: Fakultas Hukum Universitas Padjajaran. 